\title{
Electrochemical deposition of buried contacts in high-efficiency crystalline silicon photovoltaic cells
}

\author{
Jensen, Jens Arne Dahl; Møller, Per; Bruton, Tim; Mason, Nigel; Russell, Richard; Hadley, John; \\ Verhoeven, Peter; Matthewsone, Alan
}

Published in:

Journal of The Electrochemical Society

Link to article, DOI:

$10.1149 / 1.1528943$

Publication date:

2003

Document Version

Publisher's PDF, also known as Version of record

Link back to DTU Orbit

Citation (APA):

Jensen, J. A. D., Møller, P., Bruton, T., Mason, N., Russell, R., Hadley, J., Verhoeven, P., \& Matthewsone, A. (2003). Electrochemical deposition of buried contacts in high-efficiency crystalline silicon photovoltaic cells. Journal of The Electrochemical Society, 150(1), G49-G57. https://doi.org/10.1149/1.1528943

\section{General rights}

Copyright and moral rights for the publications made accessible in the public portal are retained by the authors and/or other copyright owners and it is a condition of accessing publications that users recognise and abide by the legal requirements associated with these rights.

- Users may download and print one copy of any publication from the public portal for the purpose of private study or research.

- You may not further distribute the material or use it for any profit-making activity or commercial gain

- You may freely distribute the URL identifying the publication in the public portal 


\title{
Electrochemical Deposition of Buried Contacts in High-Efficiency Crystalline Silicon Photovoltaic Cells
}

\author{
Jens A. D. Jensen, ${ }^{\text {a,b,z }}$ Per Møller, ${ }^{a}$ Tim Bruton, ${ }^{\mathrm{c}}$ Nigel Mason, ${ }^{\mathrm{c}}$ Richard Russell, \\ John Hadley, ${ }^{\mathrm{d}, *}$ Peter Verhoeven, ${ }^{\mathrm{d}}$ and Alan Matthewson ${ }^{\mathrm{e}}$ \\ ${ }^{a}$ Department of Manufacturing Engineering and Management, The Technical University of Denmark, \\ Lyngby DK-2800, Denmark \\ ${ }^{b}$ Thin Film Physics Division, Department of Physics, Linköping University, Sweden \\ ${ }^{c} B P$ Solar, European Technology Centre, Sunbury, United Kingdom \\ ${ }^{d}$ Enthone, s-Hertogenbosch, The Netherlands \\ ${ }^{e}$ The National Microelectronics Research Centre, University College Cork, Ireland
}

\begin{abstract}
This article reports on a newly developed method for electrochemical deposition of buried $\mathrm{Cu}$ contacts in Si-based photovoltaic (PV) cells. Contact grooves, $20 \mu \mathrm{m}$ wide by $40 \mu \mathrm{m}$ deep, were laser-cut into Si PV cells, hereafter applied with a thin electroless $\mathrm{NiP}$ base and subsequently filled with $\mathrm{Cu}$ by electrochemical deposition at a rate of up to $10 \mu \mathrm{m}$ per min. With the newly developed process, void-free, superconformal Cu-filling of the laser-cut grooves was observed by scanning electron microscopy and focused ion beam techniques. The $\mathrm{Cu}$ microstructure in grooves showed both bottom and sidewall texture, with a grain-size decreasing from the center to the edges of the buried $\mathrm{Cu}$ contacts and a pronounced lateral growth outside the laser-cut grooves. The measured specific contact resistances of the buried contacts was better than the production standard. Overall performance of the new PV cells was equal to the production standard with measured efficiencies up to $16.9 \%$.

(c) 2002 The Electrochemical Society. [DOI: 10.1149/1.1528943] All rights reserved.
\end{abstract}

Manuscript submitted March 25, 2002; revised manuscript received July 16, 2002. Available electronicallyDecember 13, 2002.

The industry for very large scale integrated (VLSI) electronics has been undergoing a major technology transition from $\mathrm{Al}$ alloys to damascene- $\mathrm{Cu}^{1-3}$ as the favored interconnect material for integrated circuits. Electrochemical $\mathrm{Cu}$ deposition offers several unique features for interconnect technology: $(i)$ With specific organic additives in the $\mathrm{Cu}$ electrolyte and careful process control, superconformal filling of high-aspect-ratio vias is facilitated. ${ }^{4-8}$ (ii) Electrodeposited $\mathrm{Cu}$ interconnects can show superior electromigration performance as compared to $\mathrm{Cu}$ deposited by physical vapor deposition (PVD) or chemical vapor deposition (CVD), depending on texture and grain size. $^{9,10}$ (iii) Electrodeposition is a relatively cheap process as compared to processes relying on (high) vacuum facilities; moreover, the deposition rate obtainable by electrodeposition is generally much higher than that for PVD or CVD.

In the field of Si-based buried grid photovoltaic (PV) cells, $\mathrm{Cu}$ has been the preferred choice for interconnect structures since the early 1980s. ${ }^{11,12}$ Figure 1 shows the schematic design of a buried grid PV cell. Grooves are laser-cut into the front surface of the Si wafer forming the main part of the cell. The task at hand is thus to deposit $\mathrm{Cu}$ into the grooves with good filling characteristics to ensure a good ohmic contact to the PV cell.

Electroless deposition, used at present for large-scale production, has proven to be a viable solution for the deposition of $\mathrm{Cu}$ contacts. However, incomplete filling of the laser-cut grooves in PV cells, high consumption of chemicals, a relatively slow deposition rate, and the need for narrow temperature and $\mathrm{pH}$ control has given impetus for investigating the possibility of changing the process for buried PV contacts from electroless to electrolytic $\mathrm{Cu}$ deposition. ${ }^{13}$

Under normal Butler-Volmer conditions, the current density field at the cathode is strongest at edges and corners of the geometry and weakest at the bottom of grooves (Fig. 2). ${ }^{14}$ Superconformal filling of high-aspect-ratio grooves with $\mathrm{Cu}$ therefore requires considerable process control. As can be seen from the color codes in Fig. 2, the difference in current density from the bottom of the groove to the top edge is at least two orders of magnitude.

The deposition mechanism for electrodeposited $\mathrm{Cu}$ can be controlled to a great extent by the use of organic additives, usually categorized in three groups according to their function.

Type 1 additives-levelers.-Type 1 additives, often referred to as levelers, promote the formation of smooth and bright electrodeposits. Substances with this characteristic behavior in acidic $\mathrm{Cu}$ electrolytes include compounds containing thiocarbamide groups [-C(S)$\mathrm{NH}-]$, such as thiourea and many of its derivatives, ${ }^{15,16}$ and certain cationic polymers and soluble derivatives of dithiocarbamic acid. ${ }^{17}$

Phenazonium dyestuffs, both in their monomeric and polymeric forms, have been reported as very strong levelers. ${ }^{8,13,18}$ They are known commercially under names as Janus Green, Janus Black, Neptune Blue, etc.

The exact mechanism of the individual type 1 additives is not fully understood, but some, including the phenazonium dyestuffs, seem to promote lateral growth of the electrodeposits. Typical concentrations of all these compounds range from 0.001 to $0.005 \mathrm{~g} / \mathrm{L}$. The dithiocarbamic acid derivatives can be used at considerably higher concentrations up to $20 \mathrm{~g} / \mathrm{L} .{ }^{17}$ The most powerful of the levelers, the phenazonium-dyestuffs, were used in the present study.

Type 2 additives-suppressors.-Type 2 additives, referred to as suppressors, have the ability to adhere to active plating sites on the cathode and inhibit continued deposition of metal. Added in very small quantities, so that mass transport in the electrolyte controls the number of additive molecules reaching the cathode, the suppressors hinder electrodeposition of metal at high-current-density areas (i.e., corners and edges, see Fig. 2) of the cathode.

Organic disulfides of the type $R_{1}-S-S-R_{2}$, where $R_{1}$ and $R_{2}$ may be of the same or different alkyl sulfonate groups, act as suppressors

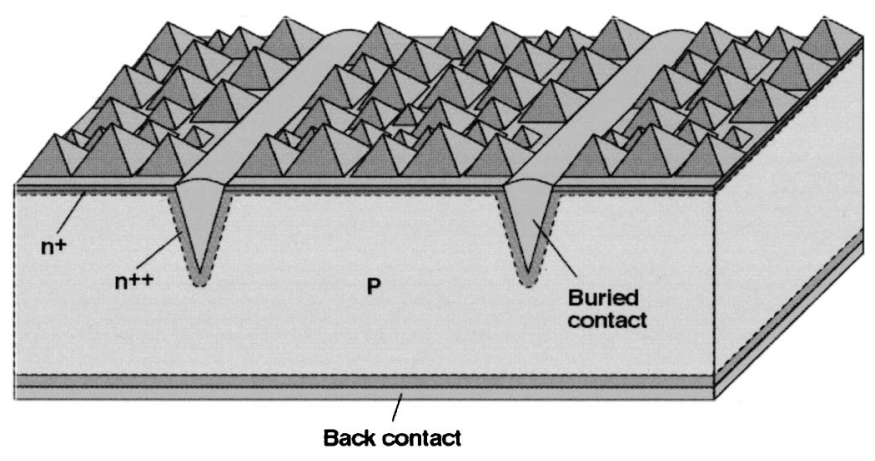

Figure 1. Schematic representation of a buried grid PV cell.

\footnotetext{
* Electrochemical Society Active Member

z E-mail: jdj@ipl.dtu.dk
} 


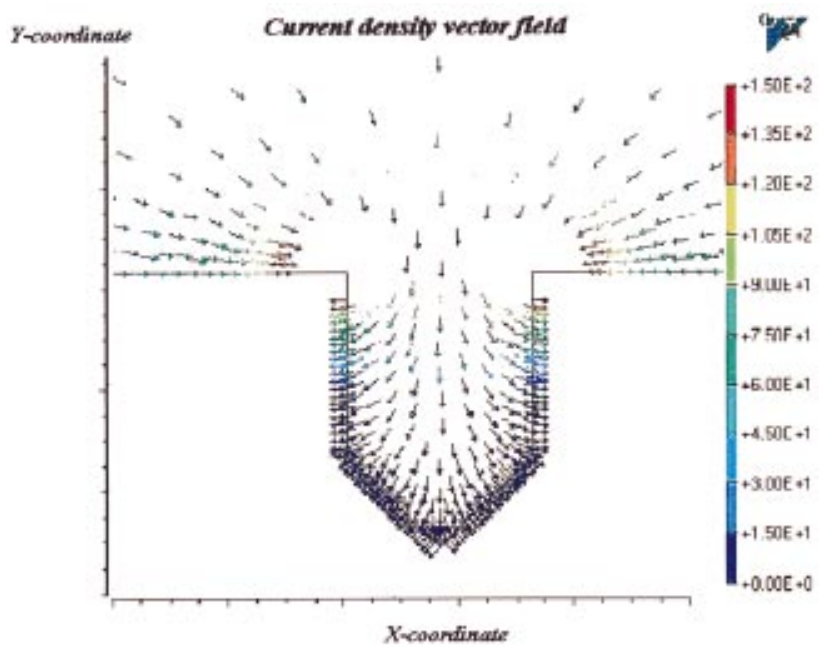

Figure 2. Qualitative current density vector field in and around groove geometry as calculated with ElSyCa electrochemical modeling software. ${ }^{13}$ The calculation was based on the following: For the anode, a linear relationship between current density and applied potential was assumed. For the cathode, a Butler-Volmer type dependency $J=J_{0} \exp (\alpha n F / R T)$ $-J_{0} \exp (-\beta n F / R T)$ where $J$ is current flux, $\alpha$ charge-transfer coefficient, $\beta=1-\alpha, n$ is the number of electrons taking part in electrochemical reaction, $F$ the Faraday constant, $R$ the gas constant, $T$ temperature in kelvin, was adopted. As can be seen from the color codes, the difference in current density from the bottom of the groove to the top edge is at least two orders of magnitude

in acidic $\mathrm{Cu}$ electrolytes. ${ }^{8,13}$ The compound bis(sodiumpropylsulfonic acid)disulfide was used in the present study. Typical concentrations of the suppressors range from 10 to $20 \mathrm{mg} / \mathrm{L}{ }^{18}$

Type 3 additives-carrier brighteners.-Often a carrier brightener is included in the $\mathrm{Cu}$ electrolyte. These compounds improve the performance of the other additives but also provide uniform, small grained, bright deposits. They ensure good wetting between the electrolyte and the cathode surface. Carrier brighteners include oxygen containing high-molecular-weight compounds (molecular weights typically $1000-20,000 \mathrm{~g} / \mathrm{mol}$ ). Examples are polyvinyl alcohol, polyethylene glycol, and polypropylene glycol. ${ }^{6,8,18}$ At concentrations down to $0.001 \mathrm{mg} / \mathrm{L}$, the type 3 additives may improve the appearance of $\mathrm{Cu}$ deposits. Typical concentrations in electrolytes range from 0.005 to $1 \mathrm{~g} / \mathrm{L}$. ${ }^{18}$

By using all three types of additives (noticing the possible strong coupling effects between additives), the deposition behavior of the electrodeposited $\mathrm{Cu}$ can be designed to match a specific substrate geometry. Details on the filling of laser cut grooves in buried grid $\mathrm{Si}$ PV cells by electrolytic $\mathrm{Cu}$ deposition are given in the following, together with a study of the resulting microstructure and properties of the deposited $\mathrm{Cu}$ contacts.

\section{Experimental}

Manufacturing procedure for buried groove PV cells.-B-doped (p-type) $125 \mathrm{~mm}^{2}$ single-crystal Si wafers with (100) crystal surface orientation were texture etched in $\mathrm{NaOH}^{\mathrm{f}}$ leaving all (111) planes exposed after the etch. The resulting textured surface reduces reflection losses from the PV cell by approximately 20\%. ${ }^{19}$ After the texture etch, an n-type emitter was formed in the cell by diffusion of elementary $\mathrm{P}$ into the front surface of the Si wafer, thus forming a p-n junction.

${ }^{\mathrm{f}}$ (111) crystal planes in Si etch slower than other Si crystal planes in $\mathrm{NaOH}$, so the etch acts anisotropically.

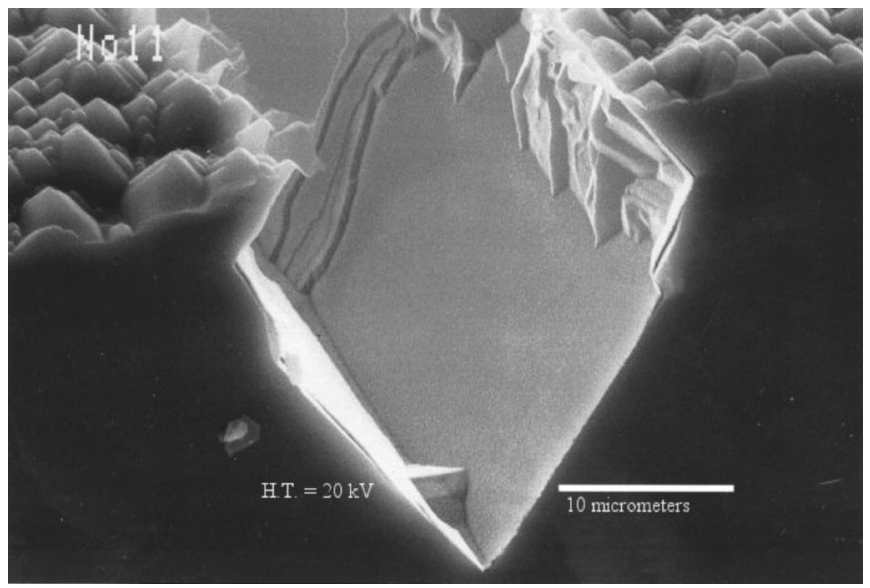

Figure 3. SEM micrograph of laser cut groove for the front contact of a buried contact photovoltaic cell. The $\{111\}$ facets at the surface remain after anisotropic $\mathrm{NaOH}$ etching. The faceted fracture seen in the groove is caused by the cross-sectioning of the cell and not the laser cutting process.

An antireflection coating of silicon nitride was subsequently formed by low-pressure chemical vapor deposition (LPCVD), using dichlorosilane and ammonia at elevated temperature. This coating also serves as a diffusion and plating mask of the Si device and is chemically resistant to subsequent chemical pretreatment and plating steps in the manufacturing process.

The front grid lines on the PV cells were laser cut into the $\mathrm{Si}$ surface, after which the grooves were doped with $\mathrm{P}$ to maintain continuity of the n-type front surface and realize a low-resistance n-type contact. A cross section of a laser cut groove is shown in Fig. 3. Al, acting as a back surface contact, was sputtered and subsequently sintered onto the back of the cell.

Hereafter the PV cell went through a series of wet chemical processes. After pickling in $\mathrm{HF}$ and rinsing with distilled water, a layer of electroless $\mathrm{Ni}$ was deposited from an alkaline electrolyte on the exposed $\mathrm{Si}$ surfaces, which act as weak catalysts for the electroless nickel process. The deposited electroless Ni layer thickness was typically on the order of $0.1 \mu \mathrm{m}$. To obtain improved contact, the electroless $\mathrm{Ni}$ deposit was sintered in an inert $\left[\mathrm{N}_{2}(\mathrm{~g})\right]$ atmosphere at $400^{\circ} \mathrm{C}$, forming a nickel silicide.

After sintering, excess $\mathrm{Ni}$ was dissolved in $\mathrm{HNO}_{3}, \mathrm{NiSi}_{2}$ was activated in $\mathrm{HF}$, and a second layer of electroless $\mathrm{Ni}$ was deposited from a weakly acidic electrolyte. This electroless Ni layer, with a thickness of about $0.1 \mu \mathrm{m}$, forms the plating base for electroless $\mathrm{Cu}$ deposition.

Following a short rinse, the PV cells were placed in an electroless $\mathrm{Cu}$ bath, where approximately $5 \mu \mathrm{m} \mathrm{Cu}$ was deposited in a 90 min batch process step to form the main part of the metal contacts in both front grooves and on the rear of the cells. The deposition sequence was concluded with an immersion $\mathrm{Ag}$ process for improved solderability.

Having concluded the plating steps, the edges of the cells were removed by laser cutting and each cell was performance tested.

The new plating procedure.-Deposition of a plating base.-The starting point for the new plating procedure was the first thin sintered electroless Ni layer deposited in the front grid grooves. This layer was reactivated in $\mathrm{HNO}_{3}$, and in order to be able to plate the sintered $\mathrm{Al}$ on the back of the cell, a further etching/activation step was carried out. ${ }^{\mathrm{g}}$

After the two-step pretreatment, the cell was introduced into a weakly acidic electroless $\mathrm{Ni}$ bath, operated at $T=75^{\circ} \mathrm{C}, \mathrm{pH}$ 4.6. A

${ }^{\mathrm{g}}$ Activation chemistry proprietary of Enthone/BP Solar. 

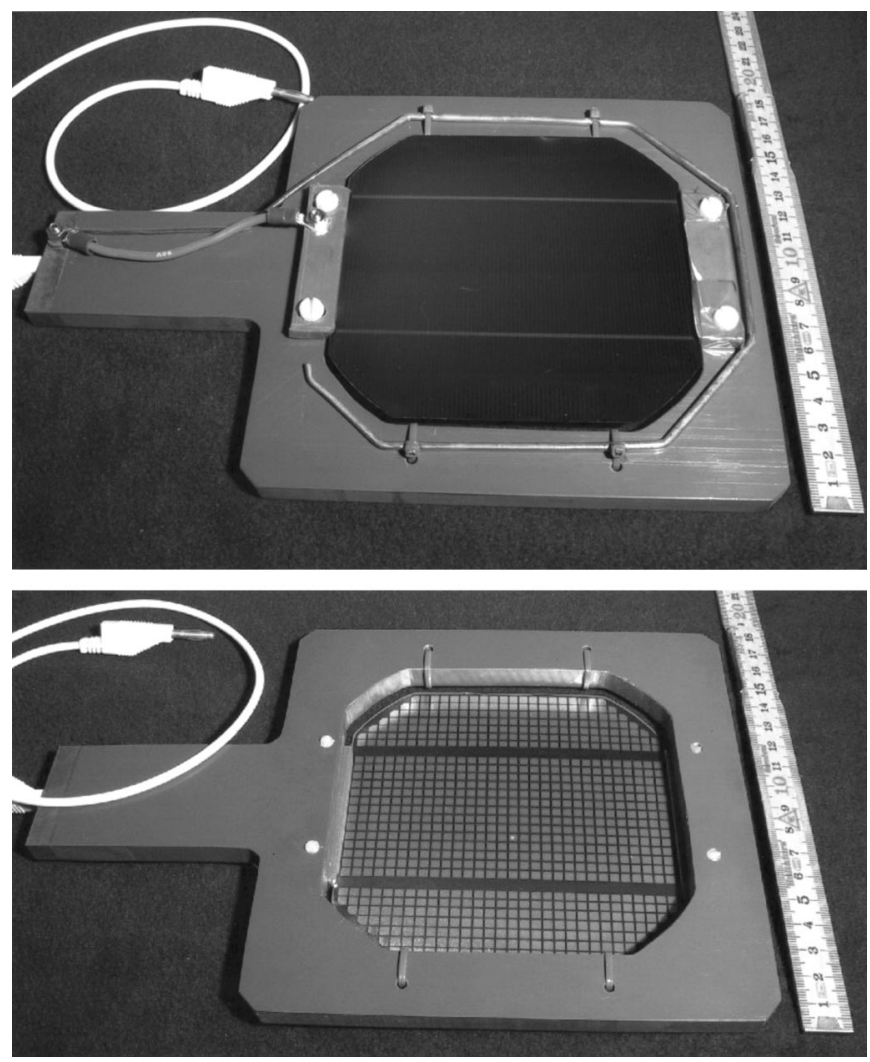

Figure 4. Mounting jig for simultaneous plating of both front and back of PV cell. Notice the current-carrying wire around the cell plated on the front of the jig for improved current density distribution on the $\mathrm{Cu}$ contact front grid of the PV cell.

proprietary electroless $\mathrm{Ni}$ process ${ }^{\mathrm{h}}$ was chosen for this work, with the following characteristics: low-P, high conductivity of the deposit, low-residual stress in the as-deposited NiP coating, high deposition rate and good leveling characteristics of coating, and stable plating electrolyte with long life and easy maintenance. A layer thickness of approximately $2 \mu \mathrm{m}$ was deposited to act as the conducting base for the subsequent electrolytic deposition of $\mathrm{Cu}$.

Contacting method.-In order to perform electrolytic deposition, current had to be applied through suitable contacting points to the plating base. A revised design of the cell contact grid allowed direct contact from the edge of the cell to the plating base in the bottom of the front grooves. A single cell mounting jig was designed, allowing simultaneous $\mathrm{Cu}$ electrodeposition on both back and front of the PV cell (Fig. 4).

Front-to-back ratio of the plateable areas on the PV cell was approximately $4 \%$, which presented a problem in allocating the main part of the deposited $\mathrm{Cu}$ mass on the back of the cell. This was achieved partly by moving the $\mathrm{Cu}$ anode facing the back of the cell closer $(d=5 \mathrm{~cm})$ to the plating jig than the anode facing the front $(d=20 \mathrm{~cm})$. To avoid disturbing electrical field lines going from back to front of the cell, a current thief ( $\mathrm{Cu}$ wire) was placed around the front-side edge of the plating jig. Preventing field lines around the cell, the current thief improved the $\mathrm{Cu}$ distribution on the front grid of the cells.

Electrolytic Cu plating.-The first electrolytic $\mathrm{Cu}$ deposition experiments were performed in a printed circuit board (PCB) type electrolyte. $\mathrm{Cu}$ electrolyte 1 , as it is referred to here, was designed to ensure uniform throwing power, irrespective of substrate geometry,
Table I. Composition and operating conditions for $\mathrm{Cu}$ electrolyte 1, designed for plating of PCBs.

\begin{tabular}{lcc} 
& Range & Optimum \\
\hline Copper sulfate $\cdot 5 \mathrm{H}_{2} \mathrm{O}$ & $60-100 \mathrm{~g} / \mathrm{L}$ & $68 \mathrm{~g} / \mathrm{L}$ \\
Copper & $15-25 \mathrm{~g} / \mathrm{L}$ & $17 \mathrm{~g} / \mathrm{L}$ \\
Sulfuric acid & $160-200 \mathrm{~g} / \mathrm{L}$ & $180 \mathrm{~g} / \mathrm{L}$ \\
Chloride ion & $40-60 \mathrm{mg} / \mathrm{L}$ & $50 \mathrm{mg} / \mathrm{L}$ \\
Inhibiting type 1 additive ${ }^{\mathrm{a}}$ & $3-5 \mathrm{~mL} / \mathrm{L}$ & $4 \mathrm{~mL} / \mathrm{L}$ \\
Temperature & $20-25^{\circ} \mathrm{C}$ & $23^{\circ} \mathrm{C}$ \\
Cathodic current density & $1-3.5 \mathrm{~A} / \mathrm{dm}^{2}$ & $2-3 \mathrm{~A} / \mathrm{dm}^{2}$ \\
Anodic current density & $0.5-1.75 \mathrm{~A} / \mathrm{dm}^{2}$ & $1 \mathrm{~A} / \mathrm{dm}^{2}$ \\
Filtration & \multicolumn{2}{c}{ Continuous }
\end{tabular}

${ }^{a}$ CUBATH SATIN additive proprietary of Enthone.

using a type 2 suppressing additive. Composition and operating conditions for this electrolyte are given in Table I.

All electrodeposition experiments were carried out in a $25 \mathrm{~L}$, air-agitated polypropylene tank with solid rod anodes of P-alloyed copper placed on both sides of the cathode (the PV cell). The electrolyte was filtered continuously ( $1 \mu \mathrm{m}$ filter cartridge). Electrodeposition was performed using a standard low-drift dc rectifier with the possibility to operate both galvanostatically and potentiostatically.

Filling characteristics of $\mathrm{Cu}$ electrolyte 1 were not optimal for the groove geometry at hand (see later Fig. 11). Instead, a bright $\mathrm{Cu}$ process, designed for maximum leveling performance, was introduced, which showed perfect filling characteristics in the laser cut grooves. Composition and operating conditions for this $\mathrm{Cu}$ electrolyte 2 are given in Table II.

The cell geometry of the PV cells implies that the effective cathode area varied considerably as the $\mathrm{Cu}$ contacts were electrodeposited. This fact made it difficult to use galvanostatic plating (constant applied current), which is most common in electrochemical deposition. Instead the relation between applied potential and cathode current density was investigated for $\mathrm{Cu}$ electrolyte 2 . The result is shown in Fig. 5.

$\mathrm{Cu}$ deposition in electrolyte 2 could be performed on the buried groove PV cells at surprisingly high current densities, resulting in high deposition rates. The best results in terms of groove filling and back contact coverage were obtained for deposition potentials between 1 and $2 \mathrm{~V}$ as read on the dc-rectifier digital readout, which according to Fig. 5 equals a current density of up to $16.5 \mathrm{~A} / \mathrm{dm}^{2}$. Deposition time was approximately $10 \mathrm{~min}$ at $U=1 \mathrm{~V}$, a reduction as compared to the 90 min deposition time needed for the electroless $\mathrm{Cu}$ process.

Table II. Composition and operating conditions for $\mathrm{Cu}$ electrolyte 2, designed for leveling.

Cu-electrolyte 2

Range

Optimum

Copper sulfate $\cdot 5 \mathrm{H}_{2} \mathrm{O}$

Sulfuric acid

Chloride ion

Brightener $\mathrm{M}^{\mathrm{a}}$

Brightener $\mathrm{L}^{5}$

Cathodic current density

Electrodeposition voltage

Anodic current density

Temperature

Agitation

Filtration

$\begin{array}{cc}180-240 \mathrm{~g} / \mathrm{L} & 225 \mathrm{~g} / \mathrm{L} \\ 45-90 \mathrm{~g} / \mathrm{L} & 56 \mathrm{~g} / \mathrm{L} \\ 20-80 \mathrm{mg} / \mathrm{L} & 60 \mathrm{mg} / \mathrm{L} \\ 1.5-2.5 \mathrm{~mL} / \mathrm{L} & 2 \mathrm{~mL} / \mathrm{L} \\ 0.1-0.5 \mathrm{~mL} / \mathrm{L} & 0,3 \mathrm{~mL} / \mathrm{L} \\ 3-6 \mathrm{~A} / \mathrm{dm}^{2} & 4 \mathrm{~A} / \mathrm{dm}^{2} \\ 3-9 \mathrm{~V} & \\ 1.5-3 \mathrm{~A} / \mathrm{dm}^{2} & 2 \mathrm{~A} / \mathrm{dm}^{2} \\ 24-32^{\circ} \mathrm{C} & \\ \text { Vigorous air agitation }\end{array}$

Continuous with no active carbon 


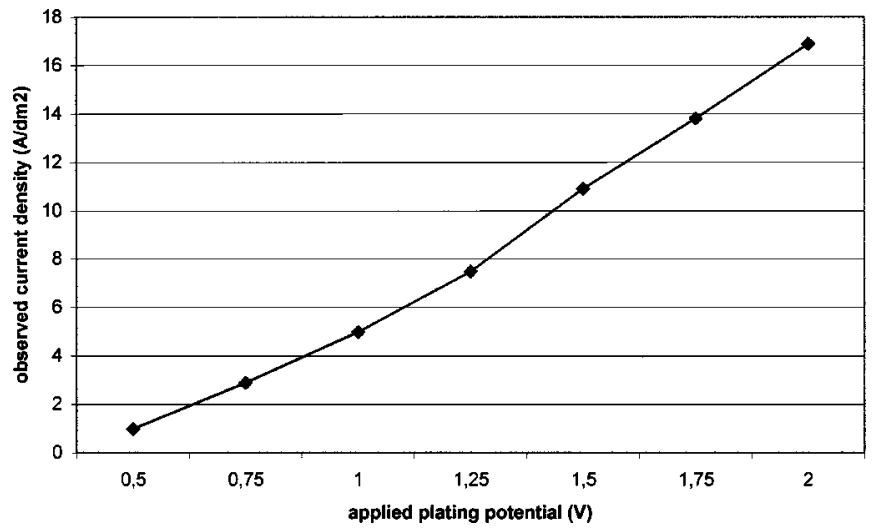

Figure 5. Current density vs. applied potential for bright copper electrolyte (Table II) used on buried contact PV cells.

As in the original procedure for the manufacture of buried grid PV cells, the plating steps were concluded by an immersion Ag coating of the $\mathrm{Cu}$ contacts, followed by laser cutting of the edges.

Scanning electron microscopy.-Scanning electron microscope (SEM) images from different V-grooves in each sample were taken using a Hitachi S-4000 (calibrated) SEM. Secondary electron imaging was used mainly, at working distances of 10-20 mm and electron accelerating voltage of $10-20 \mathrm{kV}$.

Focused ion beam analysis.-Focused ion beam (FIB) analysis was performed with a JEOL FIB system. A Cs beam was used for the sample presented here.

Contact resistance measurement.-Contact resistance was measured on samples of $4 \mathrm{~cm}^{2}$, cut from the centers of two PV cells: cell 1 electroplated $10 \mathrm{~min}$ in $\mathrm{Cu}$ electrolyte 1 (Table I) at $U=1.0 \mathrm{~V}$, and cell 2 electroplated $10 \mathrm{~min}$ in $\mathrm{Cu}$ electrolyte 2 (Table II) at $U=1.0 \mathrm{~V}$, both after 12 min electroless $\mathrm{Ni}$ deposition. Both cells were treated with a commercial, $\mathrm{H}_{2} \mathrm{SO}_{4}$-based, $\mathrm{Cu}$ cleaner before measurement of the contact resistance in order to avoid any oxide films on the $\mathrm{Cu}$ contacts.

Using a shielded hood and a Hewlett Packard 4156A precision semiconductor parameter analyzer, two probes (one for forcing a current and the other for sensing voltage) were placed in contact with a strip of copper $\left(\mathrm{I}^{+} \mathrm{V}^{+}\right)$. In the same way two other probes $\left(\mathrm{I}^{-} \mathrm{V}^{-}\right)$were placed on the second strip in order to close the circuit and enable the measurement of the effective resistance $R$ (Fig. 6).

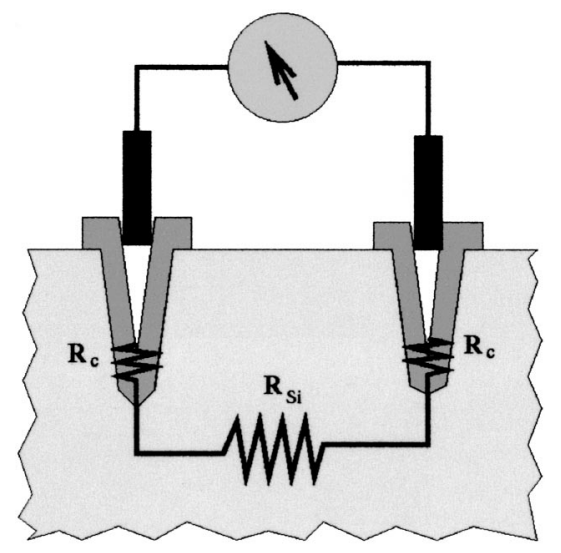

Figure 6. Schematic representation of the electrical circuit measured during the contact-resistance measurement.

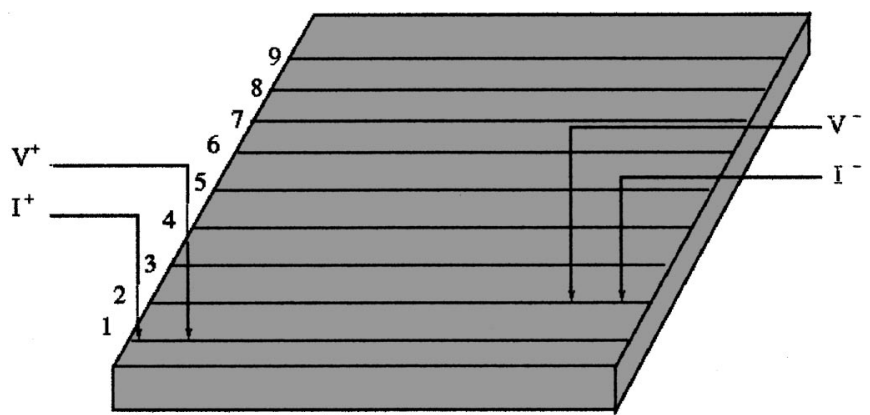

Figure 7. Contacting pattern used for the contact-resistance measurement.

The measured $R$ consists of three series components: two V-groove contact resistances and the resistance of the $\mathrm{N}_{+}$Si layer between the grooves.

Once the resistance value $(R 1,2)$ was recorded, the second set of probes was moved to a third strip where a new resistance value was recorded $(R 1,3)$. This procedure was repeated so that the maximum range of line separations possible for each sample could be measured (Fig. 7). Extrapolation of the linear dependence of $R$ on the number of lines to zero lines provides the contact resistance, $R_{\mathrm{c}}$. The slope gives $R_{\mathrm{Si}}$. Evaluation of the specific contact resistance demands an accurate value of the actual V-groove contact area. Five SEM images from different V-grooves in each sample were taken using a Hitachi S-4000 calibrated SEM. From these images the dimensions of the contact surface were obtained (Fig. 8). The specific contact resistance, $R_{\mathrm{sc}}$, was obtained by

$$
R_{\mathrm{sc}}=R_{\mathrm{c}} S
$$

where $S$ is the contact surface area.

Performance testing of the PV cell.-The finished solar cells were placed on a temperature-controlled $\left(25^{\circ} \mathrm{C}\right)$ vacuum chuck and illuminated by a collimated light source, whose spectrum was close to the standard sunlight distribution (AM1.5). A four-point contacting scheme was used in which the voltage and current leads to the cell were kept separate. This eliminated effects due to the series resistance of the test leads and associated resistances. The setup

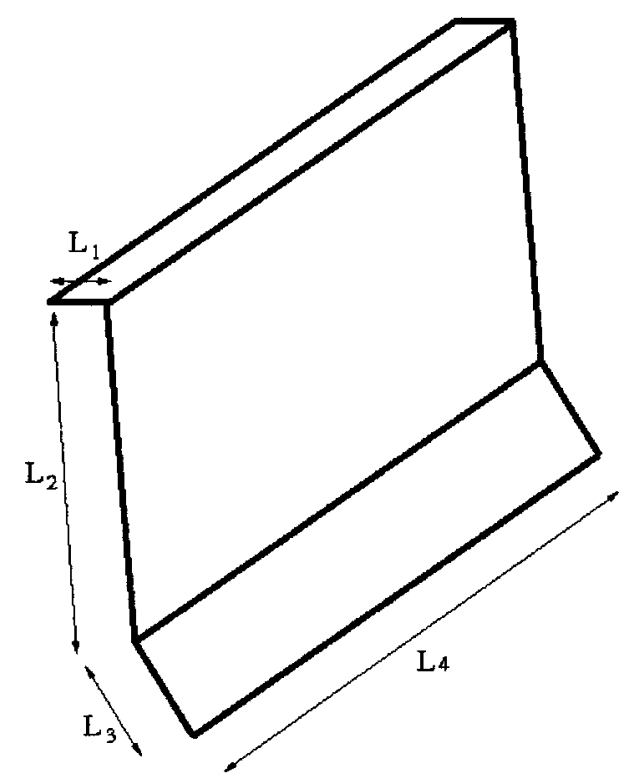

Figure 8. Schematic representation of the V-groove contact area measured in the SEM. 


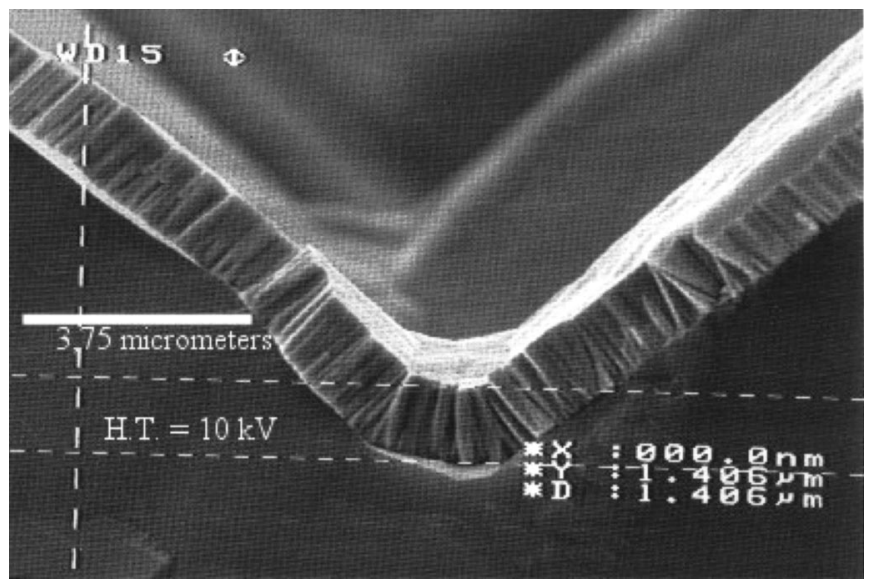

Figure 9. Electroless nickel coating in laser cut groove on PV cell. The dotted lines have been inserted during the measurement of the coating thickness $(1,406 \mu \mathrm{m})$ at the bottom of the laser cut groove.

further consisted of a voltmeter, current meter, and a variable electronic resistive load, all under PC control. The light source intensity was adjusted to a standard $1000 \mathrm{~W} / \mathrm{m}^{2}$ by measuring the shortcircuit current of a calibrated reference cell. The current-voltage characteristics of the cell were then measured by varying the electronic load resistance. From the current-voltage curve, the most important cell parameters could be derived, namely, the cell efficiency, short-circuit current $\left(I_{\mathrm{sc}}\right)$, the open-circuit voltage $\left(V_{\mathrm{oc}}\right)$, fill factor $(F F)$, series resistance $\left(R_{\mathrm{s}}\right)$, and shunt resistance $\left(R_{\mathrm{sh}}\right)$.

The fill factor, used to characterize a photovoltaic cell, is defined as the ratio of the maximum output power $\left(I_{\mathrm{mp}} V_{\mathrm{mp}}\right)$ to the $I_{\mathrm{sc}} V_{\mathrm{oc}}$, i.e., $F F=I_{\mathrm{mp}} V_{\mathrm{mp}} / I_{\mathrm{sc}} V_{\mathrm{oc}}$, and the cell efficiency is defined as $E f f=I_{\mathrm{sc}} V_{\mathrm{oc}} \mathrm{FF} / P_{\text {in }}$, where $P_{\text {in }}$ is the total power in the light incident on the cell.

\section{Results}

Electroless nickel plating base.-A cross section of the bottom of a laser cut groove with the new type of electroless Ni coating is shown in Fig. 9. As can be seen, the deposit has a columnar and quite homogeneous microstructure, and a uniform material distribution over the entire groove surface.

In electroless $\mathrm{Ni}, \mathrm{P}$ is a well-known alloying element, reducing crystal size and even forming amorphous NiP alloys, when the $\mathrm{P}$ content exceeds approximately $12 \mathrm{wt} \% .^{20-23}$ The microstructure of the NiP deposit has a strong effect on the physical properties of the coating. In the current application, one of the key properties of the deposited NiP layer is the electrical resistivity, which was found to depend linearly on the P content (Fig. 10).

Electrodeposited copper contacts.-The groove filling of the four different $\mathrm{Cu}$ processes studied here are illustrated in Fig. 11. Figure 11a shows the result of using a $\mathrm{Cu}$ electrolyte without any adjusted levels of the three types of additives mentioned previously. The electrolyte used was of the PCB type similar to $\mathrm{Cu}$ electrolyte 1 (Table I), but only with a limited amount of suppressing type 2 additive. In this electrolyte, $\mathrm{Cu}$ is deposited in accordance with the primary current distribution in the groove geometry (Fig. 2). The nodule formation at the groove edge is so extensive that the nodules hinder mass transport to the bottom of the groove, leaving a large void in the central part of the deposited contact.

Figure 11b shows the effect of stronger inhibition of highcurrent-density areas in $\mathrm{Cu}$ electrolyte 1 (Table I). The copper forms with a uniform thickness over the entire groove surface, irrespective of local current density. Although well controlled, this type of deposition behavior is not ideal for the groove geometry given, since it will leave a sharp V-void in the center of the contact on continued electrodeposition.

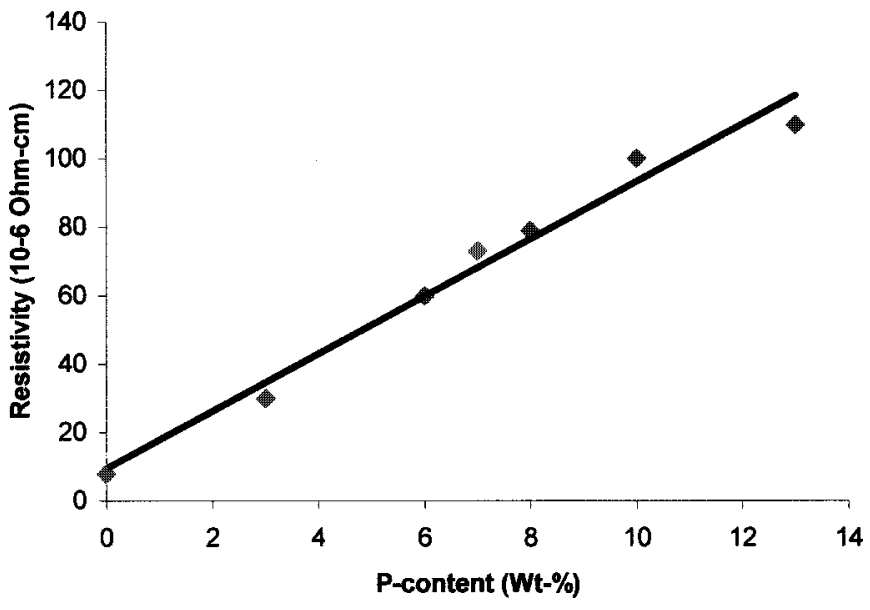

Figure 10. Electrical conductivity vs. P content in electroless NiP deposits. (Data provided by Enthone, The Netherlands.)

Figure 11c shows the filling behavior of the electroless $\mathrm{Cu}$ plating process used industrially at present. Mass transport of fresh electrolyte to the various areas of the groove is governing the observed deposition behavior. The result is quite similar to Fig. 11a.

Figure 11d shows the filling characteristics of $\mathrm{Cu}$ deposited from $\mathrm{Cu}$ electrolyte 2 (Table II). The effect of the additives used (see later discussion) is complete filling from the bottom of the groove, in direct contradiction to the current distribution present during electrodeposition (Fig. 2). This filling behavior is referred to as superconformal deposition. ${ }^{6}$

In Fig. 12 a successfully filled groove by means of superconformally electrodeposited $\mathrm{Cu}$ is shown.

Microstructure of electroplated copper contacts-FIB results.-The microstructure of the plated copper contacts produced in the optimized bright copper electrolyte can be seen on the FIB micrograph in Fig. 13. The sample investigated had been severely overplated to observe the electrodeposition behavior after the groove has been filled completely. The individual $\mathrm{Cu}$ grains growing out from the electroless Ni plating base can be clearly seen, and grain size is observed to be largest in the central region of the filled groove. The grain size of the deposited copper is reduced as the copper starts depositing on top and outside the laser cut groove, indicating strong inhibition of crystal growth during deposition in high-current-density areas (Fig. 2, see later discussion).

In the left region of the overfilling $\mathrm{Cu}$ deposit, large crystals have formed, indicating less severe inhibition of crystal growth at this point. The reason for this behavior is unclear but could simply be due to the region being sufficiently far away from the edge so that it experiences a lower current density. The electroless Ni plating base forms the only electrically conducting origin for electrodeposition, because the rest of the surface of the PV cell outside the groove is coated with a chemically stable and electrically insulating silicon nitride layer. Consequently, the part of the $\mathrm{Cu}$ deposit which is outside the groove has formed a "mushroom" shape, where it grows mainly sideways from the top of the groove. Even with no direct adhesion between the silicon nitride layer and the $\mathrm{Cu}$ electrodeposit on top of the PV cell, the deposit follows the surface contours closely. The top surface of the deposited $\mathrm{Cu}$ contact has a smooth appearance, making it ideal for applying a soldered contact.

Contact resistance.-Using the method described previously, specific contact resistances, $R_{\mathrm{sc}}$, were measured, see Table III (cell 1 refers to a PV cell with $\mathrm{Cu}$ electrodeposited from $\mathrm{Cu}$ electrolyte 1, Table I, whereas cell 2 refers to a PV cell with $\mathrm{Cu}$ contacts deposited in $\mathrm{Cu}$ electrolyte 2, Table II). Figure 14 shows cross sections taken in the SEM of buried contacts in cells 1 and 2, respectively. 


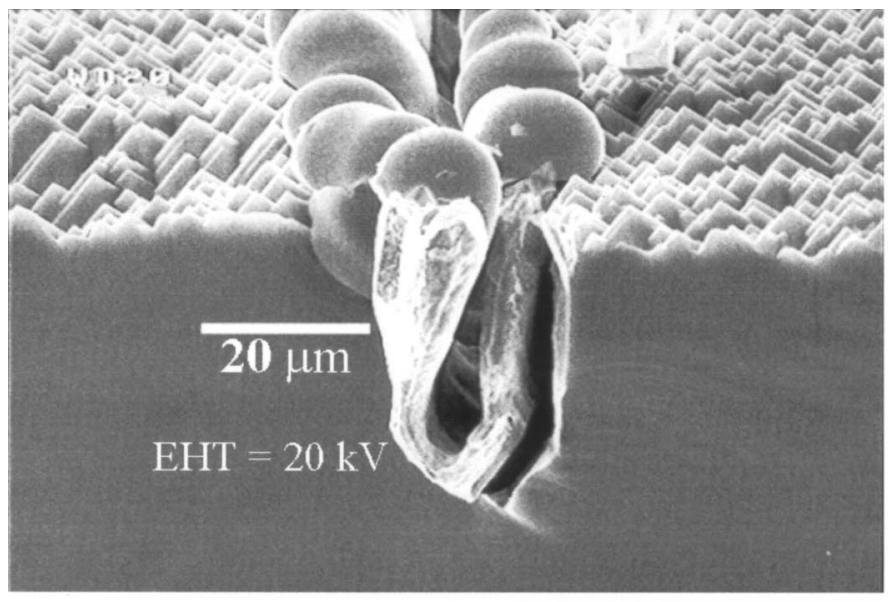

$a$

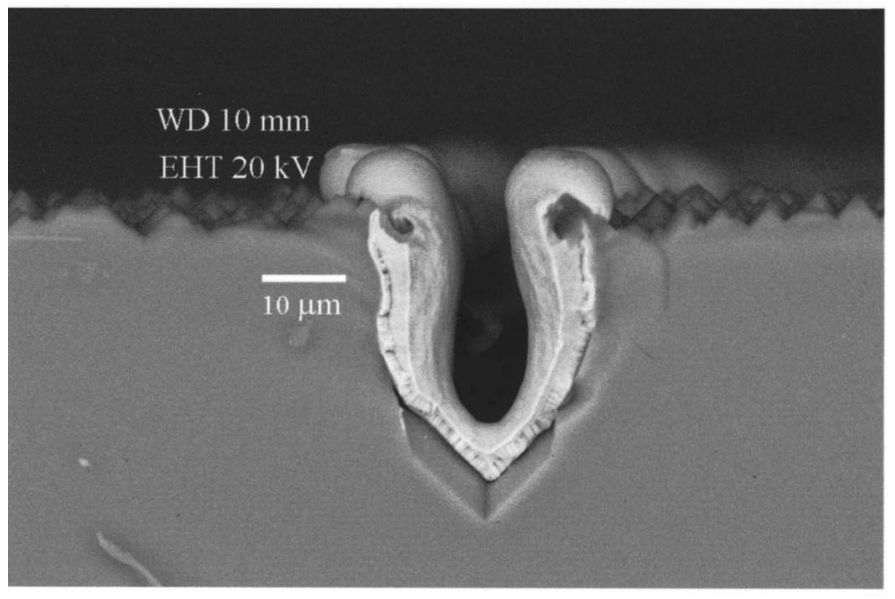

$c$

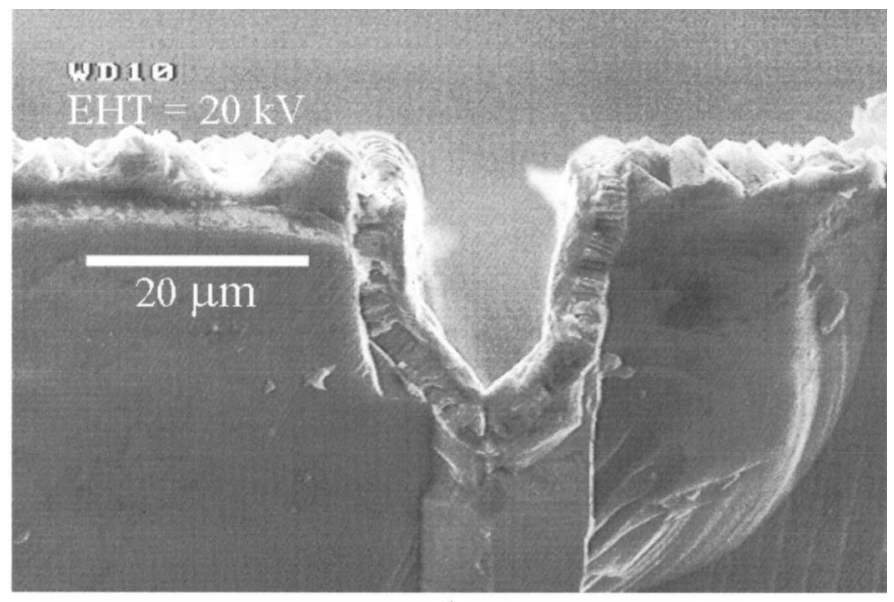

$b$

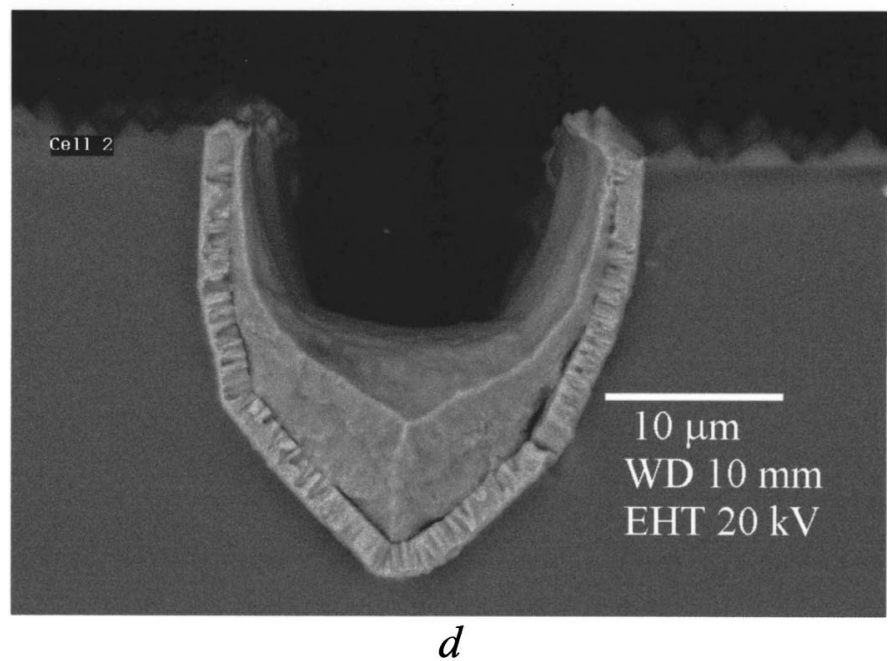

Figure 11. SEM micrographs of cross-sectioned buried groove contacts after copper deposition in four different electrolytes: (a) Cu electrodeposited into the groove geometry in a technical $\mathrm{Cu}$ electrolyte with little or no additives present. The copper has been delaminated somewhat from the Si substrate. This is not a consequence of the electrodeposition process. (b) Groove contact plated in Cu electrolyte 1 (Table I) with strong inhibiting effect of the type 2 additives used. The uniform macroleveling characteristics of the process used here manages to compensate for the differences in current density at various parts of the groove geometry (Fig. 2). The result is a uniform deposit thickness on all parts of the groove surface. Unfortunately this growth behavior creates a void in the central part of the groove when electrodeposition is continued further. (c) SEM micrograph of buried grid electroless Cu contact. The material distribution is governed by mass transport to the various parts of the groove geometry, leading to overplating at the top edges of the groove. (d) SEM micrograph of partly filled groove using $\mathrm{Cu}$ electrolyte 2 (Table II). By adjusting type 1,2, and 3 additives in the electrolyte, $\mathrm{Cu}$ fills the laser cut groove from the bottom without leaving any voids. This behavior is referred to as superconformal electrodeposition. ${ }^{19}$

Cell performance.-After some optimization in the laboratory, single PV cells with $F F=78.1$ and $E f f=16.9$ were produced. Typical values obtained from the same batch of $\mathrm{Si}$ wafers but processed by the standard production method were $F F=77$ and $E f f=16.5$.

\section{Discussion}

The electroless nickel plating base.-The main requirement for the electroless Ni layer is to provide a conducting base, with good adhesion to the Si substrate. Autocatalytic Ni deposition is facilitated by a chemical reducing agent in the electrolyte. Apart from delivering the electrons necessary for reduction of metal ions to free metal, the reducing agent often introduces alloying elements into the deposited Ni coating.

Sodium hypophosphite, $\mathrm{NaH}_{2} \mathrm{PO}_{2}$, the most frequently used reducing agent in commercial electroless $\mathrm{Ni}$ solutions, and also the one chosen in the present work, introduces $\mathrm{P}$ into the electroless $\mathrm{Ni}$ deposit. ${ }^{24} \mathrm{P}$ is a well-known alloying element, reducing crystal size and even forming amorphous NiP alloys, when the P content exceeds approximately $12 \mathrm{wt} \% .^{20-23}$ The thickness of the electroless
Ni plating base had to be optimized for the given application. With increasing thickness the current carrying capabilities of the base layer increased, but at the same time the residual tensile stresses in the deposit increased to a level where laminar cracking of the underlying Si-substrate occurred. Furthermore, the electroless Ni process is relatively slow compared to the $\mathrm{Cu}$ electrodeposition and soon becomes rate limiting in the overall manufacture of the buried contacts. A layer of approximately $2 \mu \mathrm{m}$ electroless $\mathrm{Ni}$ was found to be a good compromise between the above-mentioned factors. Compared to the electroless Ni-layer used as a plating base for the present electroless $\mathrm{Cu}$ process, this is an increase in plating base thickness by a factor of 10-20.

Apart from serving as a conducting base for the electrolytic deposition of $\mathrm{Cu}$, the electroless $\mathrm{Ni}$ layer in the laser cut grooves also acts as a diffusion barrier for $\mathrm{Cu}$. Electroless $\mathrm{NiP}$ deposits have been reported to show superior barrier performance toward $\mathrm{Cu}$ interdiffusion than pure Ni coatings. ${ }^{25,26} \mathrm{Cu}$ diffuses into $\mathrm{Si}$ at a considerable rate, even at low temperatures, where it causes recombination of exited electrons and holes. ${ }^{27,28}$ The semiconductor properties of the doped $\mathrm{Si}$ are therefore impaired if $\mathrm{Cu}$ diffusion into 

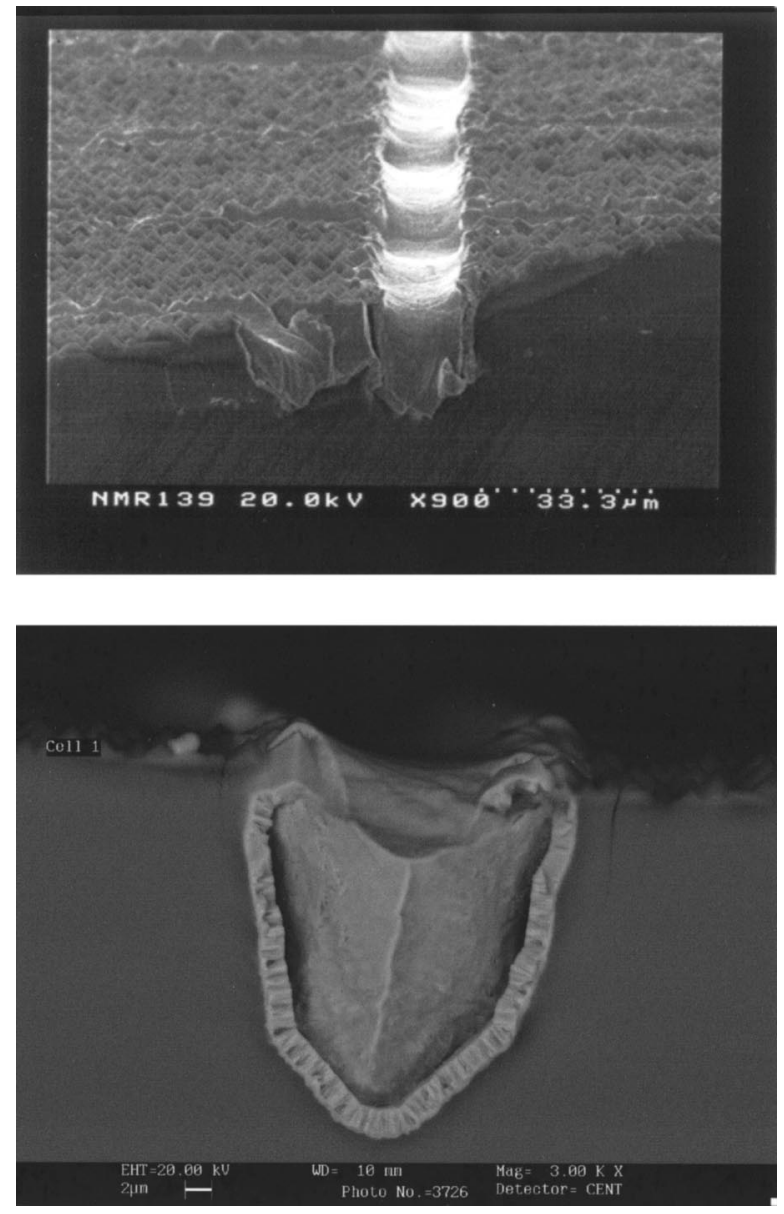

Figure 12. Surface SEM view and cross section of filled groove, electroplated in $\mathrm{Cu}$ electrolyte 2 (Table II) with adjusted type 1, 2, and 3 additive levels.

$\mathrm{Si}$ is not prevented. With good uniformity, relatively dense structure, and considerable layer thickness of the electroless $\mathrm{Ni}$ used as a plating base for $\mathrm{Cu}$ electrodeposition (Fig. 9), an effective barrier toward $\mathrm{Cu}$ interdiffusion has been established.

Interdiffusion of $\mathrm{P}$ from the NiP layer to the $\mathrm{Si}$ semiconductor device at elevated temperatures does not present a problem, since $\mathrm{Ni}$ and $\mathrm{P}$ form stable intermetallic phases such as $\mathrm{Ni}_{3} \mathrm{P}$ and $\mathrm{Ni}_{5} \mathrm{P}_{2},{ }^{29}$ hereby preventing any free $\mathrm{P}$ from diffusing.

Deposition behavior of the electrodeposited $\mathrm{Cu}$.-The key observation made in this work was the strong interaction between specific cathode geometry and additive leveling mechanism. When plating into grooves of a certain dimension, the leveling characteristics seem to change from uniform macroleveling in large grooves to microleveling or filling in small grooves.

For the PV cell groove geometry, a careful choice of the three types of additives described in the Introduction facilitated superconformal filling of grooves, based on the following: Bis(sodium propylsulfonic acid) disulfide (type 2 suppressing additive) was added in sufficient quantities to hinder nodule growth at high-currentdensity areas (Fig. 11a) without preventing electrodeposition in the laser cut grooves. Phenazonium dyestuff additives (type 1 leveling additives) were added to promote laminar growth in the bottom of the grooves, where electrodeposition occurs preferentially. Finally, some carrier brighteners (type 3 additives) were added to ensure good wetting of the active cathode areas where electrodeposition occurs, as well as improving the overall performance of the additives in the electrolyte.

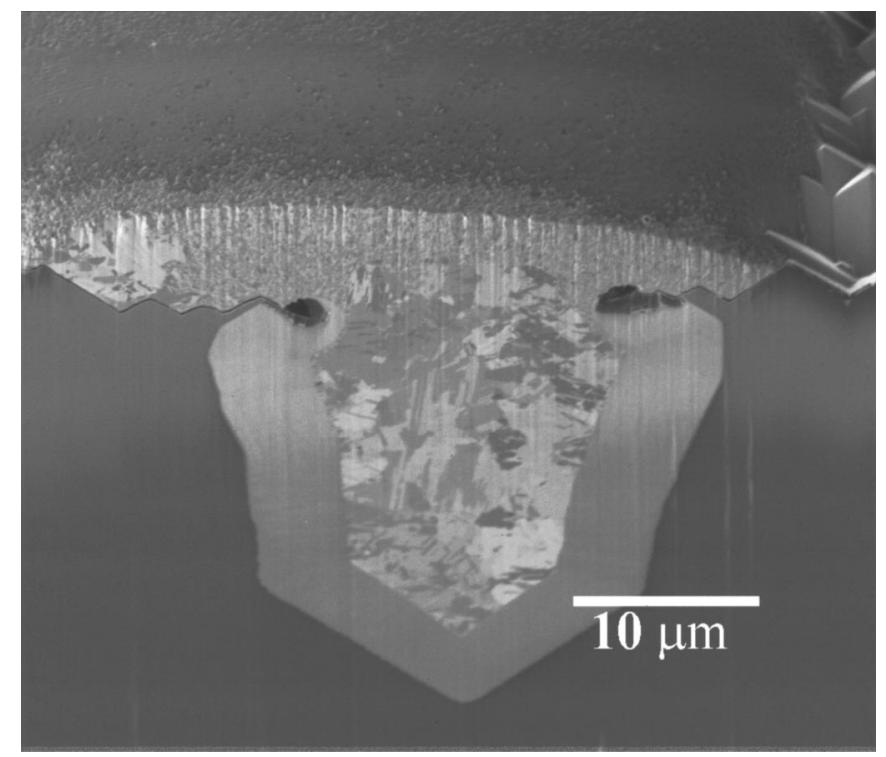

Figure 13. FIB micrograph of electrodeposited $\mathrm{Cu}$ contact. The light-gray plating base is the electroless $\mathrm{Ni}$ layer. The large $\mathrm{Cu}$ grain size in the central part of the groove indicates a low level of inhibition imposed by the organic additives in low-current-density areas, whereas the much finer grain size in the top high-current-density section of the $\mathrm{Cu}$ deposit indicates strong inhibition of crystal growth. By close inspection it can be seen that the $\mathrm{Cu}$ deposit grown sideways away from the groove does not adhere to the silicon nitride surface on the textured $\mathrm{Si}$ surface, showing how the silicon nitride acts as a chemically stable insulator during electrodeposition.

The exact groove dimensions at which the change in filling characteristics is observed varies with additive type and level. For some combinations of additives, where inhibitor additives are dominating, the change may not occur at all, as seen for instance in Fig. 11b. In other systems, where leveling additives promoting lateral growth are abundant, even quite large groove dimensions such as the ones plated here on buried groove PV cells, can be filled perfectly by a superconformal fill mechanism.

The laser cut grooves in buried grid PV cells with dimensions of $20 \mu \mathrm{m}$ wide and $40 \mu \mathrm{m}$ deep are large compared to interconnect structures in VLSI circuits with typical dimensions in the submicrometer range. Nevertheless, recent publications from the microelectronics industry have reported similar filling behavior for electroplated copper in VLSI interconnect structures manufactured by the so-called damascene- $\mathrm{Cu}$ process. ${ }^{3,4,6,8}$

The exact functionality of each additive during electrochemical deposition is still the object of some speculation. With the presence of several complex organic compounds and their various reaction products at the cathode surface, an exact analysis of each separate compound has proven difficult and will become the subject of several further studies. The studies are made difficult by the sometimes strong interactions between separate additives and the synergistic effect it has on the electrochemical deposition process.

Microstructure of electrodeposited copper.-The FIB micrograph in Fig. 13 shows that the $\mathrm{Cu}$ electrodeposit grows out from all three sides of the groove, in good agreement with previously reported X-ray diffraction (XRD) studies and texture modeling on $\mathrm{Cu}$

Table III. Calculated specific contact resistances.

\begin{tabular}{cc} 
& $R_{\mathrm{sc}}\left(\Omega \mathrm{cm}^{2}\right)$ \\
\hline Cell 1 & 0.00296 \\
Cell 2 & 0.00069
\end{tabular}




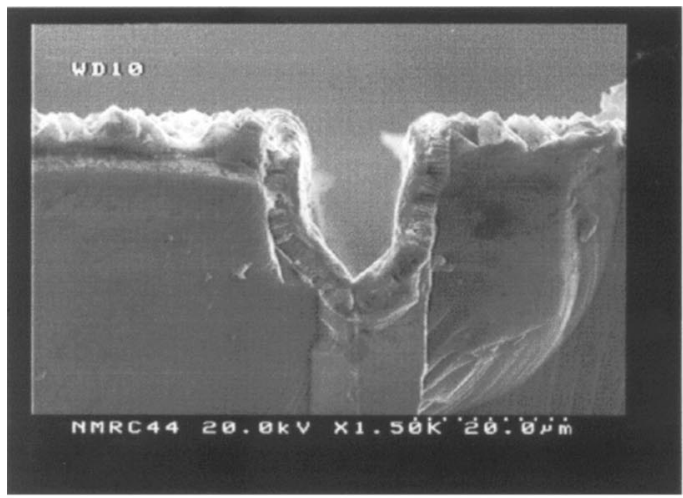

cell 1

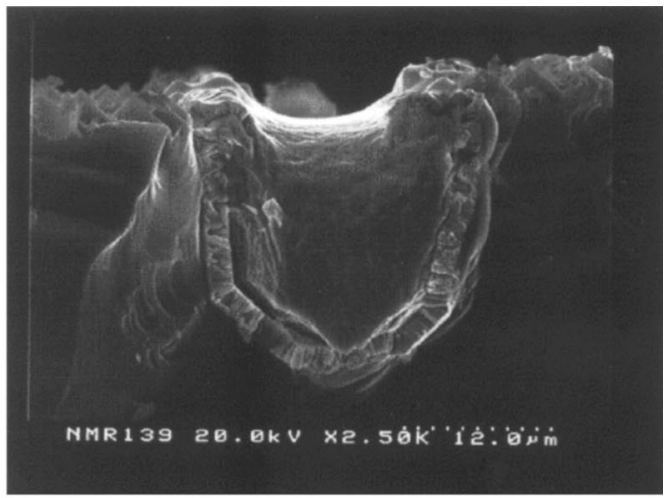

cell 2

Figure 14. Examples of the cross sections used for measurement of contact surface area. By close inspection of these micrographs, the fibrous structure in the electroless base layer can be clearly seen, and the orientation of the columnar grains in this deposit seem to be controlled to a large extent by the crystal orientation in the etched silicon substrate.

interconnects, ${ }^{30-32}$ where damascene-Cu showed (111) sidewall fiber texture and a mixed texture in the central part of the vias.

A study by Lingk et al., ${ }^{33}$ concerning the recrystallization kinetics of electrodeposited $\mathrm{Cu}$ in damascene trenches at room temperature, proposed that the recrystallization rate is higher in regions with higher internal stresses or dislocation densities and is governed by multiple twinning. Whether in fact recrystallization, i.e., the formation of new grains and their growth, or simply abnormal grain growth of the existing crystals occurs, is not quite clear from the data presented. However, the stress/dislocation theory by Lingk et al. agrees well with the observations made here. In the confined groove space, where the $\mathrm{Cu}$ is not allowed to grow freely, large crystals are observed. On top of the groove the $\mathrm{Cu}$ crystals are small. According to Lingk et al., ${ }^{33}$ full recrystallization of a $1 \mu \mathrm{m} \mathrm{Cu}$ deposit was concluded after only 1.5 days at room temperature. The sample shown in Fig. 13 was stored several weeks after $\mathrm{Cu}$ electrodeposition, before the FIB study was conducted. The observed microstructure is therefore most likely the fully recovered one. The grain size refinement at the top of the groove geometry could also be an indication of the suppressing agent trying to hinder further $\mathrm{Cu}$ electrodeposition, as the deposit develops out of the groove and becomes a high-current-density area. In a future production this possible property of the electrolytic $\mathrm{Cu}$ plating process could reduce the risk of overplating. The sample shown in Fig. 13 has actually been kept in the $\mathrm{Cu}$ electrolyte twice as long as needed in order to fill up the groove geometry. The tendency toward laminar growth caused by the strong phenazonium dyestuff leveling additives is clearly seen by the shape of the electrodeposit as it expands on top of the laser cut groove.

Contact resistance.-The filled groove contacts made by electrolytic $\mathrm{Cu}$ deposition in electrolyte 2 (Table II) showed considerably lower contact resistance values than $\mathrm{V}$-shaped $\mathrm{Cu}$ contacts made by electrodeposition in electrolyte 1 (Table I). Part of the improvement might be caused by a more uniform surface contact area, which makes it easier to make a good four-point probe measurement on a fully filled groove contact. Previous measurements made on $\mathrm{Cu}$ contacts made by electroless $\mathrm{Cu}$ deposition showed contact resistances in the order of $0.001 \Omega \mathrm{cm}^{2}$. This is to be compared with the measured value of $0.00069 \Omega \mathrm{cm}^{2}$ for the filled groove contacts and $0.00296 \Omega \mathrm{cm}^{2}$ for the V-shaped groove contacts (Table III and Fig. 14) made by electrodeposition. Considering the difficulty of probing the individual contacts with the four-point probe and the tendency for $\mathrm{Cu}$ to form oxides on the surfaces when exposed to the ambient, great care should be taken when using this technique.

Cell performance.-As mentioned in the Results section, the electrolytically deposited $\mathrm{Cu}$ contacts seem to perform at least as well as the present production standard contacts made by an electroless process. The fill factor and overall efficiency of the PV cell is very sensitive to series resistances, so any deterioration of the electrical contact between consecutively deposited layers could seriously affect the overall performance of the PV cell. In the laboratory setup used during these studies, a lot of manual handling of the PV cells may have led to less than ideal conditions for reaching the lowest possible series resistance in the cell. In an active semiconductor device such as a PV cell, photocorrosion phenomena may be observed. ${ }^{34} \mathrm{~A}$ further consequence of the numerous handling steps is an increased risk of mechanically damaging the silicon nitride antireflection coating on the front of the PV cell, leading to metal clusters forming on the front of the cell and reduced cell performance. It is therefore likely that a further increase in overall cell performance can be achieved in an optimized and automated production process.

\section{Conclusion}

The technological change from electroless to electrolytic deposition of buried $\mathrm{Cu}$ PV contacts has been proven viable. Deviations from the present industrial process (electroless) include deposition of a suitable conducting base and the development of a mounting jig for simultaneous electrodeposition of front and back contacts on PV cells. With careful optimization of electrolyte chemistry to the specific substrate geometry, superconformal filling of laser cut groves with electrodeposited $\mathrm{Cu}$ has been demonstrated within a wide range of applied current densities from 5 to $15 \mathrm{~A} / \mathrm{dm}^{2}$.

The superconformal filling behavior observed can be explained by the combined effect of preventing electrodeposition on highcurrent-density areas and promoting laminar growth in the bottom of the groove geometry, where electrodeposition takes place. Further studies are needed in order to reveal the exact functionality of each individual organic compound acting in the electrolyte during electrochemical deposition.

FIB analysis of the filled $\mathrm{Cu}$ contacts revealed a fiber-texture growth from both bottom and sidewalls of the groove, in agreement with previous XRD studies and texture modeling. ${ }^{30-32}$

Grain size in the electrodeposited $\mathrm{Cu}$ decreased from center to top of contact geometry. Possible explanations for this could be both the influence of the additives in the electrolyte as well as the internal stress level in the deposit as suggested by Lingk et al. ${ }^{30}$ The $\mathrm{Cu}$ deposit extending outside the buried groove geometry showed very strong lateral growth behavior, in good agreement with the proposed function of the phenazonium dyestuff additives (type 1 leveling additive) used in the electrolyte.

Measured contact resistances and overall cell performance for PV cells with electrolytically deposited $\mathrm{Cu}$ contacts according to the method described here have been comparable to or better than the 
existing production standard with $\mathrm{Cu}$ contacts deposited in an electroless process.

Added benefits of the new electrolytic copper plating process are reduced chemical consumption, easier operation, markedly increased deposition speed, and the possibility to go from batch to continuous conveyor manufacturing.

\section{Acknowledgments}

This work was carried out under the European Joule program for renewable energy. The authors gratefully acknowledge the financial support given by the European Commission to the project ELCOMET, electrolytic copper metallization of high-efficiency photovoltaic cells. The authors thank Professor Marcel A. J. Somers, The Technical University of Denmark, and Professor Lars Hultman, Linköping University, for reading several versions of this manuscript and for many fruitful discussions. The authors also thank Jane Boyle at BP Research and Engineering, who provided some of the SEM images presented here.

The Institute for Product Development at the Technical University of Denmark assisted in meeting the publication costs of this article.

\section{References}

1. L. Geppert, IEEE Spectrum, 1998, 23 (Jan).

2. P. Singer, Semicond. Int., 1998, 91 (June).

3. B. Chin, P. Ding, B. Sun, T. Chiang, D. Angelo, I. Hashim, Z. Xu, S. Edelstein, and F. Chen, Solid State Technol., 1998, 141 (July).

4. J. Reid, S. Mayer, E. Broadbent, E. Klawuhn, and K. Ashtiani, Solid State Technol., 2000, 86 (July).

5. R. D. Mikkola, Q.-T. Jiang, and B. Carpenter, Plat. Surf. Finish., 87(3), 81 (2000).

6. T. P. Moffat, J. E. Bonevich, W. H. Huber, A. Stanishevsky, D. R. Kelly, G. R. Stafford, and D. Josell, J. Electrochem. Soc., 147, 4524 (2000).

7. D. Varadarajan, C. Y. Lee, A. Krishnamoorthy, D. J. Duquette, and W. N. Gill, J. Electrochem. Soc., 147, 3382 (2000).
8. P. Taephaisitphongse, Y. Cao, and A. C. West, J. Electrochem. Soc., 148, C492 (2001).

9. K. Abe, Y. Harada, and H. Onoda, IEEE 98CH36173, 36th Annual International Reliability Physics Symposium, Reno, NV (1998).

10. L. Vanasupa, Y.-C. Joo, P. R. Besser, and S. Pramanick, J. Appl. Phys., 85, 2583 (1999).

11. N. B. Mason, D. Jordan, and J. G. Summers, in Proceedings of the 10th European PV Solar Energy Conference, Lisbon, April 8-12, 1991.

12. Eur. Pat. Appl. 00610081.2.

13. U.S. Pat. 4,726,850 (1988).

14. www.elsyca.com

15. U.S. Pat. 3,682,788 (1972).

16. U.S. Pat. $3,542,655(1970)$.

17. U.S. Pat. 3,798,138 (1974).

18. Correspondence with Enthone, The Netherlands.

19. M. Green, Ph.D. Thesis, p. 165, University of New South Wales, Sydney, Australia (1992).

20. P. K. Ng, D. D. Snyder, and J. La Sala, J. Electrochem. Soc., 135, 1376 (1988)

21. G. W. Marshall, D. B. Lewis, and B. E. Dodds, Surf. Coat. Technol., 53, 223 (1992).

22. G. McMahon and U. Erb, J. Mater. Sci. Lett., 8, 865 (1989)

23. C. A. Ross, L. M. Goldman, and F. Spaepen, J. Electrochem. Soc., 140, 91 (1993)

24. G. O. Mallory and J. B. Hajdu, Electroless Nickel Plating, American Electroplaters and Surface Finishers Society, Orlando, FL (1990).

25. D. A. Luke, Trans. IMF, 64, 99 (1986).

26. K. M. Chow, W. Y. Ng, and L. K. Yeung, Surf. Coat. Technol., 99, 161 (1998).

27. D. Gupta, Mater. Chem. Phys., 41, 199 (1995).

28. S. M. Sze, Semiconductor Devices-Physics and Technology, John Wiley \& Sons, New York (1985).

29. T. B. Massalski, J. L. Murray, L. H. Bennett, and H. Baker, Binary Alloy Phase Diagrams, Vol. 2, pp. 1738-1739, American Society for Metals, Materials Park, OH (1986).

30. C. Lingk, M. E. Gross, and W. L. Brown, Appl. Phys. Lett., 74, 682 (1999).

31. E. Zschech, W. Blum, I. Zienert, and P. R. Besser, Z. Metallkd., 92, 803 (2001).

32. S. P. Riege and C. V. Thompson, Scr. Mater., 41, 403 (1999).

33. C. Lingk, M. E. Gross, and W. L. Brown, J. Appl. Phys., 87, 2232 (2000).

34. Y. Homma, S. Kondo, N. Sakuma, K. Hinode, J. Noguchi, N. Ohashi, H. Yamaguchi, and N. Owada, J. Electrochem. Soc., 147, 1193 (2000). 